\title{
Influence of in vitro Micropropagation Growth Conditions on Stomatal and Morphological Characteristics of Mature Pistacia vera $\mathrm{L}$.
}

\author{
Emine AYAZ TILKAT ${ }^{1}$, Hülya HOŞGÖREN ${ }^{2}$, Alevcan KAPLAN ${ }^{3 *}$, Engin TILLKAT ${ }^{1}$
}

\begin{abstract}
This research was conducted to reveal the stomatal anatomy, stomatal index and water loss (\%) of mature pistachio leaves as well as the leaves of different phases (multiplication, rooting, hardening and regenerated plant) of micropropagation of mature pistachio trees obtained from the in vitro. Microscopic observations on surfaces of these leaves showed variety from elliptical to ovate stomata with length of 0.81-2.02 $\mu \mathrm{m}$ and width of 1.58-3.80 $\mu \mathrm{m}$. An increase in stomatal index (SI) in the leaves of plants grown in vitro was observed most specifically in the hardening phase. (17.49 \pm 0.04$)$. The stomatal index declined in the leaves of plantlets transferred to in vivo conditions subsequent to the hardening phase. In order to measure water loss, leaves obtained from all types of samples were dried in the oven between 30 minutes and 2 hours and weighed. The percent water loss of in vitro leaves of multiplication phase was greater than the other phases. The stomatal differentation was found to be influenced by the different hardening regimes applied. Hardening by covering the pots with polyethylene bags improved the survival rate. This study indicates that optmization of in vitro micropropagation stages is necessary to avoid transplantation stress.
\end{abstract}

Keywords: Hardening, in vitro culture, stomatal characteristics, water loss, stomatal index, P. vera $\mathrm{L}$.

\section{Olgun Antepfıstığı'nın (Pistacia vera L.) Stomatal ve Morfolojik Özellikleri Üzerine In vitro Mikropropagasyon Büyüme Koşullarının Etkisi}

Özet: Bu çalışma, olgun antepfıstığı ağaçlarının in vitro olarak mikroçoğaltımının farklı evrelerinden (çoğaltma, köklendirme, alıştırma ve rejenere bitki) elde edilen yaprakların stoma anatomisini, stoma indeksini ve su kaybını (\%) ortaya çıkarmak için yapılmıştır. Yaprak yüzeyinde yapılan mikroskobik gözlemler, 0.81-2.02 $\mu \mathrm{m}$ uzunluğunda ve 1.58-3.80 $\mu \mathrm{m}$ genişliğinde eliptikten ovat stomaya kadar çeşitlilik göstermiştir. In vitro yetiştirilen bitkilerin özellikle alıştırma aşamasında yapraklarında stoma indeksinde (SI) bir artış gözlenmiştir

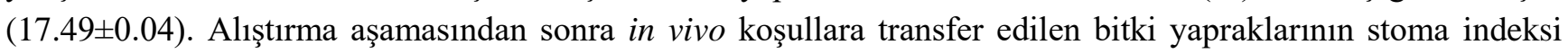
azalmıştır. Su kaybını ölçmek için, her çeşit numuneden elde edilen yapraklar, 30 dakika ile 2 saat arasında firında kurutularak tartılmıştır. Çoğaltma aşamasındaki su kaybı yüzdesinin diğer aşamalara göre daha büyük olduğu tespit edilmiştir. Stoma farklılaşmasının, uygulanan doğal şartlara aktarım metodu tarafından da etkilendiği tespit edilmiştir. Saksıların polietilen poşetlerle kapatılması yoluyla gerçekleştirilen aklimatizasyon yönteminin yaşama oranını arttırdığı tespit edilmiştir. Bu çalışma, transplantasyon stresinden kaçınmak için in vitro mikro-çoğaltma aşamalarının optimizasyonunun gerekli olduğunu göstermektedir.

Anahtar Kelimeler: Alıştırma, in vitro kültür, stoma özellikleri, su kaybı, stoma indeksi, $P$. vera $\mathrm{L}$.

\footnotetext{
${ }^{1}$ Emine AYAZ TİLKAT (Orcid ID: 0000-0001-5111-425X), Engin TİLKAT (Orcid ID: 0000-0002-1654-7655), Faculty of Science and Literature, Department of Biology, University of Batman, 72060 Batman, Turkey.

${ }^{2}$ Hülya HOŞGÖREN (Orcid ID: 0000-0002-3528-3157), Faculty of Science, Department of Biology, University of Dicle, 21280 Diyarbakır, Turkey.

3 Alevcan KAPLAN (Orcid ID: 0000-0001-6738-7527), Sason Vocational School, Department of Crop and Animal Production, University of Batman, 72060 Batman, Turkey.
}

* Corresponding Author: Alevcan KAPLAN, e-mail: kaplanalevcan@gmail.com

The study was presented as a poster at 20th National Biology Congress on 21 - 25 June in Denizli. 


\section{INTRODUCTION}

Micropropagation that cause rapid growth and multiplication of shoots under in vitro conditions often lead to the formation of plantlets with abnormal morphology, anatomy and physiology (Mohamed and Alsadon, 2010). Therefore, a significant amount of micropropagated pistachio plantlets could be lost or harmed especially during the period of acclimatization to ex vitro conditions (Zobayed et al.,2001). The main parameters of these controlled culture conditions include constant temperature, high relative humidity (RH), low photosynthetic photon flux (PPF), optimized concentrations of salts, carbonhydrates and plant growth regulators (Kubato et al.,1997). Among them incubation of plantlets at high RH could be considered to be the most important parameter as it could cause high mortality rate during ex vitro transfer mainly due to the excessive water loss attributed to reduced leaf epicuticular wax (Sutter and Langhans, 1979) high stomatal densities (Desjardins, 1988) and poor stomatal functioning (Blanke and Belcher, 1989). The reason for the poor functioning of stomata could be due to the guard cell wall characteristics (Ziv et al., 1987), deformation of stomata (Blanke and Belcher, 1989) or $\mathrm{K}^{+}$overflow through the guard cells (Assmann, 1993).

Although several improvements were made for the initiation, multiplication and rooting of pistachio, up to now, only one study was reported on stoma morphology of micropropagated pistachio (Barghchi,1982; Bustamante-Garcia, 1984; Al Ramadhani, 1985; Martinelli, 1988; Abousalim, 1990; Gonzales and Frutos, 1990; Yang and Ludders, 1993; Onay, 1996; Onay et al.,1997; Onay, 2000; OzdenTokatlı et al.,2005; Tilkat et al., 2008; Tilkat and Onay, 2009; Tilkat et al., 2009). However, a detailed study on stomatal anatomy, stomatal index and water loss (\%) should be carried out in micropropagated pistachio (Namlı and Ayaz, 2007) plantlets to reveal out the status and function of stoma during different phases of micropropagation. Besides, the transfer of plantlets from in vitro culture containers to air conditions is still considered to be the one of the most challenging steps of some woody species together with pistachio (Chandra et al.,2001; Joshi et al., 2006; Mišalová et al., 2009; Balakrishnan et al., 2009; Moyo et al.,2012) as well as pistachio. Thus, the purpose of this study was to investigate stomatal and morghological characteristics of $P$. vera L. leaves during different stages of micropropagation and to develop a method for successful hardening of pistachio plantlets during their rapid propagation.

\section{MATERIALS AND METHODS}

\section{Establishment of In vitro Culture Conditions}

Vigorous new shoots were collected from adult Pistacia vera L. trees (25-year-old) at Pistachio Research Institute in Gaziantep, South-east of Turkey, during the month of April, for the experiment. Shoot cultures, were started from aseptically grown adult trees of $P$. vera $\mathrm{L}$. according to the method defined by (Tilkat, 2006). Adventitious buds from the initiation medium were repeatedly subcultured every 3 weeks on a MS (Murashige and Skoog, 1962) media supplemented with $1.0 \mathrm{mg} \mathrm{L}^{-1}$ BA (6benzyladenine). This culture was preserved for more than three years. Long shoots $(>3 \mathrm{~cm}$ long) collected after the third subculture were used for in vitro rooting. Shoots longer than $3 \mathrm{~cm}$ were transported to a rooting media consisting of MS media with $5.5 \mathrm{~g} \mathrm{~L}^{-1}$ agar, $30 \mathrm{~g} \mathrm{~L}^{-1}$ sucrose and $2.0 \mathrm{mg}$ $\mathrm{L}^{-1}$ IBA (indole-3-butyric acid). Cultures were maintained at $25 \pm 2{ }^{\circ} \mathrm{C}$, with $40 \mu \mathrm{mol} \mathrm{m} \mathrm{m}^{-2} \mathrm{~s}^{-1}$ for $16 \mathrm{~h}$ photoperiod and $60-70 \%$ relative humidity.

\section{Applied Hardening Conditions}

In vitro regenerated plantlets were subjected to the following mode of hardening: 1) Rooted microplants were directly transported to ex vitro conditions. 2) The plants in pots were covered with 
polyethylene bags for $20 \mathrm{~d}$ followed by gradual opening and complete removal after the next $20 \mathrm{~d} 3$ ) Rooted microplants were hardened in vitro in a culture coated with pyrex glasses containing autoclaved peat and perlite moistened with $1 / 2$ MS nutrients after the 14th day, followed by gradual opening and complete removal after the next 40 days. All those operations were carried out in a growth chamber where the temperature was $25 \pm 2^{\circ} \mathrm{C}$ and the relative humidity was decreased from $90 \%$ to $50 \%$ by using an evaporative cooling system.

\section{Stomatal Analyses}

When the plants were completely weaned ( 4 to 6 weeks), they were exposed to greenhouse conditions. For peeling preparation, leaves were collected and used from the top node at different stages of micropropagation (multiplication, rooting, hardening, regenerated plant). Controls included leaves obtained from field-grown trees of $P$. vera L. (25 years old). In order to determine the stoma characteristics, together with control, five plantlets from each phase, twenty leaves from each plantlets and ten peels from each leaf were examined. In the case of the stomatal index (the number of stomata per unit area), the length of the stomata, the width of the stomata, the epidermis of the ventral parts were all peeled and placed on a glass slide, mounted with distilled water and covered with a cover slip. Prepared slides were observed under an inverted microscope. The stomatal index (SI) was determined on the leaf lamina zones, using the following formula of Salisbury, 1927:

$\mathrm{SI}=\mathrm{S} /(\mathrm{E}+\mathrm{S}) \times 100$,

where $\mathrm{S}$ is the number of stomata per unit leaf area and $\mathrm{E}$ is the number of epidermal cells per unit leaf area.

The size of the stomata was measured with the aid of an ocular micrometer, pre-calibrated with a stage micrometer. The shape and the size of the leaves (width and length) were measured and compared.

The morphological characteristics of the leaves obtained during different phases of micropropagation were also reported. Moreover, leaf colours were identified as either light green (translucence) or dark green (opaque).

\section{Water Loss Analyses}

Almost, in order to determine the amount of water loss, fresh weight of leaves with similar size (two out of five plants) were weighed to determine water loss (Table 4). Leaves were allowed to transpire by keeping their abaxial edges, on clean bench at room temperature of $23-27^{\circ} \mathrm{C}$ and relative humidity of 35-40 \%. Each leaf was weighed at $30 \mathrm{~min}$. interval for $2 \mathrm{~h}$. Lastly, all tested leaves were dried at 60 ${ }^{\circ} \mathrm{C}$ to obtain dry mass. Water loss was calculated as defined by Brainerd and Fuchigami, 1981:

Water loss $(\%)=[($ Initial Fresh Mass-Mass After Holding $) /($ Fresh Mass-Dry Mass $) \times 100]$

\section{Statistical Analyses}

For all treatments were conducted using a completely randomized block design was used. Significance was determined by an analysis of variance, and the least significant $(\mathrm{P} \leq 0.05)$ differences among mean values were estimated using Duncan's New Multiple Range test. Data presented in percentages were subjected to chi-square $(\chi 2)$ analysis. Analysis of variance, was used to find differences between treatments in comparing stomatal density, diameter and length. Duncan Multiple Range Test, was used to differentiate mean values and significant effects were accepted at $p \leq 0.05$. Data calculations were performed using SPSS for Windows (version 15.0, SPSS ${ }^{\circ}$, Chicago, USA). 


\section{RESULTS AND DISCUSSION}

\section{Morphological Characteristics}

Morphology of the leaves changed in shape (width x length) and colour as shown in Figure 1. A$\mathrm{E}$ and Table 1. The leaves developed in the multiplication phase were a light green and eliptic shapes, whereas leaves developed rooting phase had greenish yellow colour and ovate or eliptic shapes. Moreover the leaves of in vitro hardening phase with eliptic-ovate shapes with dark green and the leaves of regenerated plantlets had round-ovate shapes with dark green colour. In case of the control (fieldgrown-tree) leaves broad-ovate shapes these were thin and with light green or green colur and eliptic or ovate shape. The shape measured as the width and the length of the leaves was also altered in the micropropagation phases tested; these had greater length than width. The width and length of mature tree leaves were significantly higher than the leaves obtained from different stages of micropropagation. However, leaves taken from all tested phases had greater length than width, similar to the mature tree.

As a result of this study, it was determined that in vitro differentiation of leaf morphology and stoma were affected by micropropagation phases and the type of hardening. This confirms the previous data on stomatal morphology reported on different plant species (Marin, 1988; Zacchini, 1997). Thus, epidermal peels of different phases of micropropagation appear to be different with decreasing stomatal index. This trend was particularly marked with the hardening type tested. Leaf shape and color deviations was apparent at different micropropagation stages. The reversibility, differentiated between the different phases induced by the above-mentioned treatment (Table 1), was different in the leaves investigated in vitro at different stages and appears to exclude/include the possibility that the stomatal reaction, which was obscured at such high percentages, could be due to completely physical and chemical factors. Hyperhydricity caused transculent thin and brittle leaves including also malformation of stoma. This phenomenon is also a serious problem during in vitro culture of mangosteen (Te chato et al., 2005).

Table 1. Morphological characteristics of leaves obtained in the course of different phases of micropropagation.

\begin{tabular}{lcccc}
\hline Source of Leaf & Shape of Leaf & Colour & Width $(\mathbf{c m}) \mathbf{(} \pm$ SD)* & Length $(\mathbf{c m})( \pm$ SD) \\
\hline Multiplication Phase & Eliptic & Light Green & $0.81 \pm 0.53^{\mathrm{c}}$ & $1.58 \pm 0.12^{\mathrm{c}}$ \\
Rooting Phase & Eliptic-Ovate & Greenish Yellow & $0.83 \pm 0.36^{\mathrm{c}}$ & $1.58 \pm 0.10^{\mathrm{c}}$ \\
In vitro Hardening & Eliptic-Ovate & Dark Green & $0.85 \pm 0.08^{\mathrm{c}}$ & $1.65 \pm 0.30^{\mathrm{c}}$ \\
Regenerated Plantlets (1 year old) & Round Ovate & Dark Green & $1.56 \pm 0.13^{\mathrm{b}}$ & $2.75 \pm 0.20^{\mathrm{b}}$ \\
Mature Tree (30 years-old) & Ovate or Broad Lanceolate & Dark Green & $2.02 \pm 0.36^{\mathrm{a}}$ & $3.80 \pm 0.30^{\mathrm{a}}$
\end{tabular}

\section{Stomatal Characteristics}

According to our analysis, the epidermal cells on the leaves obtained from the cultures at the end of the replication phase were polygonal, having no curved fluctuations in the anticline walls. (Fig. 1F). The stomata of the leaves obtained from the cultures of this phase were either wide open, or with equal guard cells. These stomas had a rounded morphology with more porous area. Such irregularities, were also common during the rooting and hardening phase (Fig. 1G-1H). Irregularly shaped epidermal cells (with or without fluctuations) were observed in the micropropagation phase while curved fluctuations were detected during the rooting phase in pistachio.(Fig. G). The fact remains that, stomata in leaves collected from the regenerated plantlet (Fig. 1I) and mature tree of pistachio (Fig. 1K) were anomocytic, elliptical (different from kidney formed guard cells) and isodiametric epidermal cells. The significantly highest stomatal index (17.49) was obtained in leaves collected from in vitro hardening phase while the lowest index was found in leaves of regenerated plantlets and mature tree (10.85 and 10.96, 
respectively). It was observed that the stomata in the leaves obtained from all stages of the micropropagation were similar in length and width, but the multiplication phase was different from them (Table 2). When the stomata in the leaves obtained from the multiplication phase were compared with the mature pistachio tree, the stomata in the multiplication phase were almost round and spherical porous (20.27 $\mu \mathrm{m}$ length and $18.19 \mu \mathrm{m}$ width), while the stomata of the mature pistachio tree were elliptical (22.64 $\mu \mathrm{m}$ length and $17.40 \mu \mathrm{m}$ width). The stomatal density was highest in leaves from hardening cultures (17.49). The values obtained in other micro-propagation stages were determined in multiplication phase (13.31), rooting phase (11.35), regenerated plants (10.85) and mature tree (10.96), respectively.
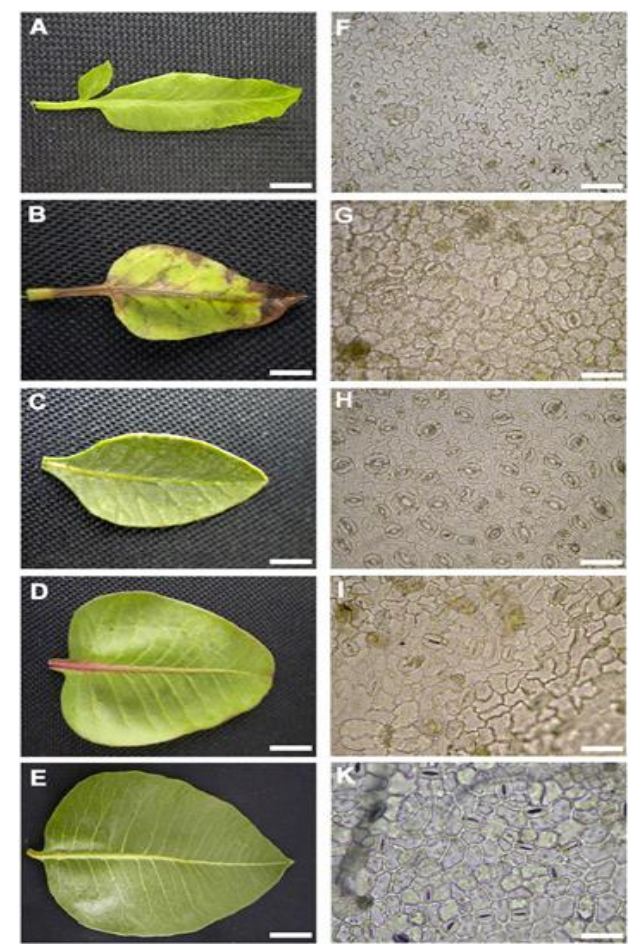

Fig.1. Morphological (A-E) characteristics of leaves obtained from different phases of micropropagation. Leaves from: AMultiplication Phase, (bar: $5 \mathrm{~mm}$ ); B- Rooting phase, (bar: $5.4 \mathrm{~mm}$ ); C- Hardening phase, (bar: $5.6 \mathrm{~mm}$ ); D- Regenerated plantlets, (bar: $7.6 \mathrm{~mm}$ ); E- Mature tree, (bar: $12.5 \mathrm{~mm}$ ); Chracteristics and distrubition of stoma (F-K) in epidermal layer of: F- Multiplication phase leaf, (bar: $47.04 \mu \mathrm{m}$ ); G- Rooting phase leaf, (47.04 $\mu \mathrm{m}$ ); H- Hardening phase leaf, (bar: $44.11 \mu \mathrm{m})$; I- Regenerated plantlets leaf, (bar: $47.04 \mu \mathrm{m})$; K- Mature tree leaf, (bar: $44.11 \mu \mathrm{m}$ ).

The stomatal index during the in vitro hardening phase was almost twice of regenerated plantlets and the mature tree. This diffential behaviour could be correlated with the percentage of malformed stomata. Stomatal differentation was found to be influenced by the different hardening regimes applied (Table 3). The highest value of stomatal index was induced by transferring the plantlet to pots covered with polyethylene bags. Relatively lower stomatal index was obtained in leaves collected from pots covered with pyrex glasses while data could not be taken from leaves of direct transfer, those plantlets could not survive beyond a few hours. Although the length of the stomata was higher in leaves collected from pots covered with polyethylene bags, the width of the stomata was relatively lower in this treatment than stomatas on leaves of pots covered with pyrex glasses. Significant differences have emerged in the successful acclimatisation of plantlets between the different types of hardening (Table 3). The highest density of acclimatised plantlets was $80 \%$ in pots covered with polyethylene bags and $90 \%$ of these plants survived when transferred to soil. Pots covered with pyrex glasses also resulted in high frequency 
of acclimatized plantlets $(70 \%) .90 \%$ of viable regenerants was also obtained after 6 months transfer to growth room conditions.

Table 2. Stomatal characteristics of Pistacia vera L. leaves in the course of different phases of micropropagation (Means \pm $\mathrm{SE}, \mathrm{n}=5)$

\begin{tabular}{lccc}
\hline Source of Leaf & $\begin{array}{c}\text { Stomatal Index } \\
(\boldsymbol{\%})^{*}\end{array}$ & $\begin{array}{c}\text { Length of Stomata } \\
{[\boldsymbol{\mu m}]^{*}}\end{array}$ & ${\text { Width of Stomata [ } \boldsymbol{\mu m}^{*}}^{*}$ \\
\hline Multiplication Phase & $13.31 \pm 0.02^{\mathrm{b}}$ & $20.27 \pm 0.08^{\mathrm{d}}$ & $18.19 \pm 0.06^{\mathrm{a}}$ \\
Rooting Phase & $11.35 \pm 0.04^{\mathrm{c}}$ & $23.52 \pm 0.08^{\mathrm{b}}$ & $15.42 \pm 0.06^{\mathrm{d}}$ \\
In vitro Hardened & $17.49 \pm 0.04^{\mathrm{a}}$ & $24.70 \pm 0.05^{\mathrm{a}}$ & $15.28 \pm 0.06^{\mathrm{d}}$ \\
Regenerated Plantlets & $10.96 \pm 0.06^{\mathrm{d}}$ & $24.18 \pm 0.07^{\mathrm{a}}$ & $16.92 \pm 0.04^{\mathrm{c}}$ \\
Mature Tree & $10.85 \pm 0.04^{\mathrm{d}}$ & $22.64 \pm 0.04^{\mathrm{c}}$ & $17.40 \pm 0.06^{\mathrm{b}}$ \\
\hline * Different lower-case letters in each column indicate that these values are statistically different at P $\leq 0.05$ according to \\
Duncan's Multiple Range Test.
\end{tabular}

Table 3. Effect of hardening type on stomatal characteristics and viable regenerants (\%) of P.vera. L. leaves.

\begin{tabular}{|c|c|c|c|c|c|}
\hline Type of Hardening & $\begin{array}{l}\text { Stomatal } \\
\text { Index* }\end{array}$ & $\begin{array}{c}\text { Length of } \\
\text { Stomata }[\mu \mathrm{m}] \\
*\end{array}$ & $\begin{array}{l}\text { Width of } \\
\text { stomata } \\
{[\mu \mathrm{m}]^{*}}\end{array}$ & $\begin{array}{c}\% \text { of } \\
\text { Acclimatized } \\
\text { Regenerant } * *\end{array}$ & $\begin{array}{c}\text { Viable Regenerants } \\
\text { (\%) After Six Months } \\
\text { Transfer to Growth } \\
\text { Room*** }\end{array}$ \\
\hline $\begin{array}{l}\text { Pots covered with } \\
\text { Polyethylene Bags }\end{array}$ & $23.32 \pm 0.07^{\mathrm{a}}$ & $23.16 \pm 0.08^{\mathrm{a}}$ & $14.42 \pm 0.04^{b}$ & 80 & 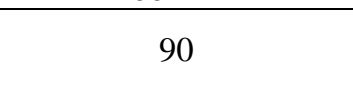 \\
\hline $\begin{array}{l}\text { Pots Coated with Pyrex } \\
\text { Glasses }\end{array}$ & $21.78 \pm 0.08^{b}$ & $20.25 \pm 0.02^{\mathrm{b}}$ & $17.24 \pm 0.04^{\mathrm{a}}$ & 70 & 90 \\
\hline $\begin{array}{l}\text { Direct Transfer } \\
\chi^{2}(\mathrm{df})\end{array}$ & $00.00 \pm 0.00^{c}$ & $00.00 \pm 0.00^{\mathrm{c}}$ & $00.00 \pm 0.00^{\mathrm{c}}$ & $\begin{array}{c}0 \\
\mathrm{P} \leq 0.05\end{array}$ & $\begin{array}{c}0 \\
\mathrm{P} \leq 0.05 \\
\end{array}$ \\
\hline
\end{tabular}

There may be many causes of decreased stoma function over time in vitro. Probably as a result of high relative humidity, in vitro plantlets cellulose deposits seem to be reduced, compared to in vivo conditions (Marin, 1988).

According to this evidence, the earliest leaves, in our experiments also could have a lower stomata index since they were submitted for a longer period of time to high relative humidity. Similar results have also been reported by (Zacchini et al., 1997). When the Wrightia tomentosa cultures were transferred to a low relative humidity level, no deformation of the stoma morphology was recorded in the leaves of in vivo hardened plants.

Our results strongly suggest that the stomatal index is affected by the different phases of micropropagation; index, width and length of the stomatas are also influenced by the hardening type used. (Table 3.) Therefore, the results of this study indicate that enhancement of the micropropagation phases in vitro is neccessary to avoid transplantation stress. This would then lead to a higher survival rate and a greater yield. A relationship was observed between the stoma index and different stages of micropropagation. However, the gradual change in stomata shape from eliptical in the early phases (multiplication and rooting) to circular in mature leaves is noteworthy.

\section{Water Loss}

The maximum water loss $(69.70 \%)$ was observed in the leaves from multiplication phase within the first $30 \mathrm{~min}$. (Table 4). In the same period, the water losses was $65.62 \%$ for leaves of rooted 
microplants, $61.80 \%$ for in vitro hardened plants, $34.50 \%$ for regenerated plants, $13.95 \%$ for the leaves of the mature tree, respectively.

Except the mature tree in other all cases, the percentage of water loss decreased with time. Within 2 hours, maximum water loss was observed in multiplication phase at the rate of $97.23 \%$. When the seedlings were gradually exposed to in vivo conditions, water loss control have increased with time. In vitro study of Actinidia deliciosa plantlets found that the water loss value gradually decreased (Moncalean et al., 2009). This result is similar to our study.

Table 4. Water loss (\%) from decomposed leaves of plantlets in the course of different phases of micropropagation in Pistacia vera $\mathrm{L}$. (Means \pm SE of 5 plants).

\begin{tabular}{lccccc}
\hline $\begin{array}{l}\text { Time } \\
(\mathbf{m i n})\end{array}$ & Multiplication* & Rooting* & $\begin{array}{c}\text { In vitro Hardened } \\
\text { Plants }^{*}\end{array}$ & $\begin{array}{c}\text { Regenerated } \\
\text { Plantlets* }^{*}\end{array}$ & $\begin{array}{c}\text { Mature } \\
\text { Tree* }^{*}\end{array}$ \\
\hline $0-30$ & $69.70 \pm 1.85^{\mathrm{a}}$ & $65.62 \pm 0.28^{\mathrm{a}}$ & $61.80 \pm 0.67^{\mathrm{a}}$ & $34.50 \pm 0.25^{\mathrm{a}}$ & $13.95 \pm 0.25^{\mathrm{bc}}$ \\
$30-60$ & $23.77 \pm 0.71^{\mathrm{b}}$ & $17.94 \pm 0.35^{\mathrm{b}}$ & $15.18 \pm 0.27^{\mathrm{b}}$ & $15.17 \pm 0.91^{\mathrm{b}}$ & $22.63 \pm 0.36^{\mathrm{a}}$ \\
$60-90$ & $2.75 \pm 0.13^{\mathrm{c}}$ & $7.49 \pm 0.02^{\mathrm{c}}$ & $12.12 \pm 0.02^{\mathrm{c}}$ & $11.66 \pm 0.71^{\mathrm{c}}$ & $13.16 \pm 0.38^{\mathrm{c}}$ \\
$90-120$ & $1.01 \pm 0.19^{\mathrm{d}}$ & $1.99 \pm 0.05^{\mathrm{d}}$ & $7.44 \pm 0.18^{\mathrm{d}}$ & $4.74 \pm 0.04^{\mathrm{d}}$ & $14.75 \pm 0.06^{\mathrm{b}}$ \\
\hline
\end{tabular}

* Different lower-case letters in each column indicate that these values are statistically different at $\mathrm{P} \leq 0.05$ according to Duncan's Multiple Range Test.

\section{CONCLUSION}

This study was performed to reveal the stomatal anatomy, stomatal index and water loss (\%) of mature pistachio leaves as well as the leaves of different phases (multiplication, rooting, hardening and regenerated plant) of micropropagation of mature pistachio trees obtained from the in vitro. The results of our study were corroborate the results obtained by Zacchini et al., (1997) who suggest that the circular shape of in vitro stomata is not a characteristic of the early differentation stages, but rather occurs as a gradual process over time. It can be expressed that it is necessary to optimization micropropagation steps in order to obtain high survival rates of in vitro propagated pistachio seedlings after adaptation to in vivo conditions.

\section{REFERENCES}

Abousalim A, 1990. Micropropagation and Micrografting of Pistachio (P. vera L. and Pistacia atlantica Desf.). Wye College, University of London, UK, Department of Horticulture, Ph.D. Thesis (Printed).

Al Ramadhani RMA, 1985. The effect of some growth regulator on the initiation and growth of Pistacia vera L. Mosul University, Mosul (Iraq) College of Science.

Assmann SM, 1993. Signal transduction in guard cells. Annual Review of Cell and Developmental Biology, 9: 345- 375.

Balakrishnan V, Ram Latha M, Ravindran KC and Robinson JP, 2009. Clonal Propagation of Morus alba L. through Nodal and Axillary Bud Explants. Botany Research International, 2 (1): 42-49.

Barghchi M, 1982. In vitro propagation of Pistacia species. University of Nottingham, UK, Ph.D. Thesis (Printed).

Blanke MM, Belcher AR, 1989. Stomata of apple leaves cultured in vitro. Plant Cell, Tissue and Organ Culture, 19: 85- 89.

Brainerd KE, Fuchigami LJ, 1981. Acclimatization of aseptically cultured apple plants to low relative humidity. Journal of the American Society for Horticultural Science, 106(4):515- 518.

Bustamante-Garcia MA, 1984. Micropropagation and Rejuvenation of Pistacia species and the mechanism by which light influences root initiation. University of California, Davis, USA, Ph.D. Thesis (Printed). 
Chandra Dang J, Kumaria S, Kumar S and Tandon P, 2011. Micropropagation of Ilex khasiana, a critically endangered and endemic holly of Northeast India. AoB PLANTS, Plro 012. DOI:10. 1093/aobpla/plr012.

Desjardins Y, Laforge C, Lussier C, Gosselin A, 1988. Effect of $\mathrm{CO}_{2}$ enrichment and high photosynthetic photon flux on the development of autotrophy and growth of tissue-cultured strawberry, raspberry and asparagus plants. Acta Horticulturae, 230: 45- 53.

Gonzales A, Frutos D, 1990. In vitro culture of Pistacia vera L. embryos and aged tree explants. En Plant Aging: Basic and Applied Approaches. No:186, pp. 335- 338. Plenum Publishing Corporation, New York.

Joshi P, Joshi N, Purohit SD, 2006. Stomatal characteristics during micropropagation of Wrightia tomentosa. Biologia Plantarum, 50(2): 275- 278.

Kubota C, Fujiwara K, Kitaya Y, Kozai T, 1997. Recent advances in environmental control in micropropagation. In: Goto E, Kurata K, Hayashi M, Sasa S, eds. Plant production in closed ecosystems. Dordrecht: Kluwer Academic Publishers, 153-169.

Marin JA, Gella R, Herrero M, 1988. Stomatal structure and functioning as a response to environmental changes in acclimatized micropropagated Prunus cerasifera L. Annual Review Botanic, 62: 662670.

Martinelli A, 1988. Use of in vitro techniques for selection and cloning of different Pistacia species. Acta Horticulture, 227. 436- 437.

Mišalová A, Jurkovič J, Mamoňová M, Priwitzer T, Lengyelová A, Hladká D, Lux A, 2009. Changes in leaf organisation, photosynthetic performance and wood formation during ex vitro acclimatisation of black mulberry (Morus nigra L.). Plant Biology, 11(5): 686-693.

Mohamed MAH, Alsadon AA, 2010. Influence of ventilation and sucrose on growth and leaf anatomy of micropogated potato plantlets. Scientia Horticulturae, 123.295- 300.

Moncalean P, Fal MA, Castanon S, Fernandez B, Rodriguez A, 2009. Relative water content, in vitro proliferation, and growth of Actinidia deliciosa plantlets are affected by benzyladenine. New Zealand Journal of Crop and Horticultural Science, 37: 351-359.

Moyo M, Finnie JF, Staden JV, 2012. Microculture effects on leaf epidermis and root structure in Sclerocarya birrea subsp. caffra, South African Journal of Botany, 78: 170-177.

Murashige T, Skoog F, 1962. A revised medium for rapid growth and bioassays with tobacco tissue cultures. Physiologia Plantarum, 15: 473- 497.

Namli S, Ayaz E, 2007. Influence of different cytokinins used in in vitro culture of the stoma morphology of pistachi. African Journal of Biotechnology, 6(5):561- 563.

Onay A, 1996. In vitro organogenesis and embryogenesis of pistachio, Pistacia vera L. University of Edinburgh, UK. Ph.D. Thesis (Printed).

Onay A, Firat M Z, Namlı O, 1997. An improved method for embling production in Pistachio, Pistacia vera L. using liquid medium matured somatic embryos. Turkish Journal of Biology, 21: 159- 174.

Onay A, 2000. Micropropagation of pistachio from mature trees. Plant Cell, Tissue and Organ Culture, 60, 159- 162.

Ozden-Tokatl1 Y, Ozudogru EA, Akcın A, 2005. In vitro response of pistachio nodal explants to silver nitrate. Scientia Horticulturae, 106: 415- 426.

Salisbury EJ, 1927. On the causes and ecological significance of stomatal frequency with special reference to woodland flora. Philosophical Transactions of the Royal Society of London, series B. 216 (1928): 1- 65. 
Sutter E, Langhans RW, 1979. Epicuticular wax formation on carnation plantlets from shoot tip culture. Journal of the American Society for Horticultural Science, 104: 493- 496.

Te chato S, Petsut P, Nuchum P, 2005. Effect of gelling agents on shoot growth and multiple shoot formation of mangosteen. Songklanakarin Journal of Science and Technology, 27: 637- 643.

Tilkat E, Onay A, Yıldırım H, Ozen HC, 2008. Micropropagation of mature male pistachio Pistacia vera L., The Journal of Horticultural Science \& Biotechnology, 83(3):328-333.

Tilkat E, Onay A, 2009. Direct shoot organogenesis from in vitro derived mature leaf explants of pistachio, In Vitro Cellular \& Developmental Biology - Plant, 45: 92- 98.

Tilkat E, Onay A, Y1ldırım H, Ayaz E, 2009. Direct plant regeneration from mature leaf explants of pistachio, Pistacia vera L., Scientia Horticulturae, 121(3): 361-365.

Tilkat E. 2006, Micropropagation of Male Pistacia vera L. via Apical Shoot Tip Culture, Institute of Science, University of Dicle, Ph.D. Thesis (Printed).

Yang Z, Ludders P, 1993. In vitro propagation of Pistachio (Pistacia vera L.). Gartenbauwissenschaft 59: $30-34$.

Zacchini M, Morini S, Vitagliano C, 1997. Effect of photoperiod on some stomatal characteristics of in vitro cultured fruit tree shoots. Plant Cell, Tissue and Organ Culture, 49: 195- 200.

Ziv M, Schwartz A, Fleminger D, 1987. Malfunctioning stomata in vitreous leaves of carnation (Dianthus caryophyllus) plants propagated in vitro; implications for hardening. Plant Science Letters, 52: 127- 134.

Zobayed SMA, Armstrong J, Armstrong W, 2001. Leaf anatomy of in vitro tobacco and cauliflower plantlets as affected by different types of ventilation. Plant Science, 161: 537-548. 